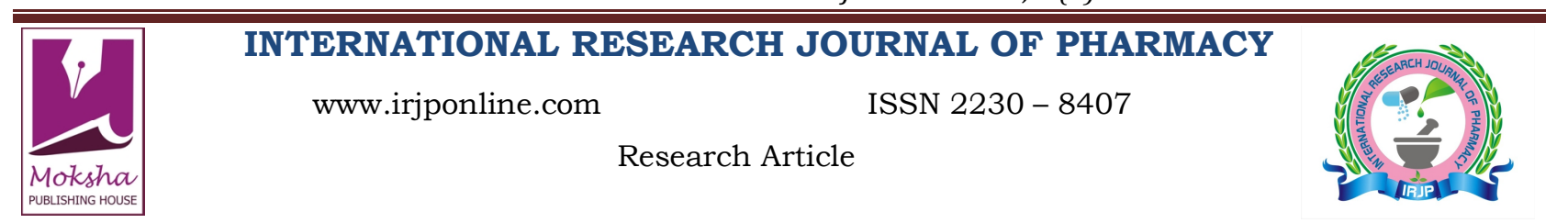

\title{
EVALUATION OF THE RELATIVE INCIDENCE OF ADVERSE EFFECTS LEADING TO TREATMENT DISCONTINUATION OF RECOMMENDED ANTIHYPERTENSIVE DRUGS \\ Yakubu Sani $\mathrm{Ibn}^{1}{ }^{*}$, Fave Tata ${ }^{1}$, Giwa Abdulganiyu ${ }^{1}$, Muazu Jamilu ${ }^{2}$ and Mohammed Garba Tom ${ }^{2}$ \\ ${ }^{1}$ Department of Clinical Pharmacy and Pharmacy Administration, Faculty of Pharmacy University of Maiduguri, Nigeria \\ ${ }^{2}$ Department of Pharmaceutics and Pharmaceutical Microbiology, Faculty of Pharmacy University of Maiduguri, Nigeria \\ *Corresponding Author Email: sanibnyakubu@googlemail.com
}

Article Received on: 14/03/13 Revised on: 08/04/13 Approved for publication: 11/05/13

DOI: 10.7897/2230-8407.04613

IRJP is an official publication of Moksha Publishing House. Website: www.mokshaph.com

(C) All rights reserved.

\section{ABSTRACT}

This study aimed at evaluating the incidence of adverse effects leading to treatment discontinuation of antihypertensive drugs within the same therapeutic class. Individual medical records were searched to identify those hypertensive patients who had been commenced on antihypertensive therapy during a $24-$ month period and who had subsequently for a reason(s) discontinued the therapy. The results showed variation in discontinuation rates for drugs within same class, and that might be related to the relative frequency of specific adverse effects. Cough was the reason cited for discontinuation of angiotensin converting enzyme inhibitors, with linosopril appearing to be better tolerated than captopril (39\% vs $48 \%)$; peripheral oedema with calcium channel blockers, with amlodipine appearing to be better tolerated than nifedipine $(29 \% \mathrm{vs} 38 \%)$ and bradycardia with beta adrenergic receptor blockers, with propranolol better tolerated than atenolol ( $0 \%$ vs $48 \%)$. Diuretics showed the lowest discontinuation rate $(3.3 \%)$ mainly due to hypokalemia, with thiazide better tolerated than frusemide $(11 \%$ vs $43 \%)$.

Prescribers should verify their use of antihypertensive drugs to ensure that they prescribe drugs with lower adverse effect rates, in order that patients with hypertension continue using the medication in the long term, thereby reducing the risk of developing cardiovascular complications associated with uncontrolled blood pressure.

Keywords: antihypertensive drugs, adverse effect, discontinuation, treatment

\section{INTRODUCTION}

Hypertension is a medical condition where the systolic blood pressure (SBP) is more than $140 \mathrm{~mm} \mathrm{Hg}$ and the diastolic blood pressure (DBP) is more than $90 \mathrm{~mm} \mathrm{Hg}^{1}$. Uncontrolled hypertension can lead to heart disease, stroke, renal failure and retinopathy ${ }^{2}$. These are the principal causes of death in all developed countries and are emerging as a prominent public health problem in developing countries ranking third with mainly $16 \%$ of all deaths ${ }^{3}$. The prevalence of hypertension in Nigeria varied extensively between studies, ranging from a minimum of $12.4 \%$ to a maximum of $34.8 \%{ }^{4}$. Antihypertensive drugs are medicines that lower blood pressure. There are various categories of antihypertensive drugs and each has some adverse effects. The UK Commission on Human Medicine defines an adverse drug reaction (ARD) as an unwanted or harmful reaction experienced after the administration of a drug or combination of drugs under normal condition of use and suspected to be related to the drug 5 . Among the recommended and most widely used antihypertensive drugs are the diuretics, the angiotensin converting enzyme (ACE) inhibitors, the calcium channel blockers (CCBs), the beta adrenergic receptor blockers, and the angiotensin II receptor antagonists $\mathrm{ARBs}^{6,7}$. Despite the plethora of blood pressure (BP) lowering agents, satisfactory control of hypertension is often difficult to achieve. This is in part due to the adverse effects associated with the various antihypertensive drugs, which are a cause for the discontinuation of treatment ${ }^{8}$. Several studies ${ }^{9-}$ ${ }^{12}$ had been carried out on adverse drug reactions (ADRs) related to antihypertensive drugs in some parts of the world, the results demonstrated high frequency of ADRs in antihypertensive treatment, but with significant differences between the various drug groups ${ }^{13}$ and between antihypertensive drugs within the same therapeutic group, leading to the discontinuation of treatment. ${ }^{14}$
Maiduguri is a metropolitan city in the north eastern Nigeria, a region which to the best our knowledge has not been evaluated for incidence of adverse effects of antihypertensive drugs. Therefore, the objective of this retrospective study was to evaluate the relative incidence of adverse effects of antihypertensive drugs, leading to treatment discontinuation among patients diagnosed with hypertension, who attended the Cardiology Unit of the Department of Medicine, University of Maiduguri Teaching Hospital (UMTH) Maiduguri.

\section{MATERIALS AND METHOD \\ Setting}

The retrospective study was carried out at the Cardiology Unit of the Department of Medicine, University of Maiduguri Teaching Hospital (UMTH) Maiduguri Borno State, Nigeria.

\section{Data collection process}

Ethical clearance was obtained from the Ethics and Research Committee of the hospital prior to the commencement of the study. The methodology was adopted from Baqir [14] with modifications. Patients with hypertension (who were not diagnosed with co-morbid diseases such as diabetes mellitus, dyslipidemia, heart failure and hepatic dysfunction) were identified from the Cardiology Unit, medical records system using clinical codes. Individual records were then searched to identify those patients who had been commenced on antihypertensive therapy during 24-month period (January 2008-December 2009) and who had subsequently discontinued that therapy. Though a sample size determination formula: $\mathrm{nf}=\mathrm{n} / 1+\mathrm{n} / \mathrm{N}(\mathrm{nf}=$ sample size for population less than 10,$000 ; \mathrm{n}=$ sample size for population greater than 10,000 and $\mathrm{N}=$ estimate for population of study) was supposed to have been used for a target population of less than 10,000, because of the precision desired in the study 
the entire population, comprising 1164 patients` folders, was used.

Further scrutiny of the patients' records was then undertaken to ascertain the reason(s) for the discontinuation of antihypertensive therapy. A self-designed data collection format (appendix I) was used for collection of all relevant data.

\section{Data analysis}

The data obtained were statistically analyzed using Statistical Package for Social Sciences SPSS Version 16, and the results were presented as frequency and percentage of adverse effects experienced from each class of antihypertensive drugs. Proportions were compared using chi-square analysis, p-values $<0.05$ were considered significant.

Table 1: Distribution of adverse drug effect within each class of antihypertensive

\begin{tabular}{|c|c|c|c|}
\hline $\begin{array}{c}\text { Class of antihypertensive } \\
\text { drug }\end{array}$ & $\begin{array}{c}\text { Total exposure } \\
\text { (prescriptions) of drugs }\end{array}$ & \multicolumn{2}{|c|}{$\begin{array}{c}\text { Any documented of adverse drug effect (incidence) within class of } \\
\text { antihypertensives }\end{array}$} \\
\cline { 2 - 4 } & & Yo & $35(4.7 \%)$ \\
\hline Diuretics & 749 & $714(95.3 \%)$ & $88(12.3 \%)$ \\
\hline ACEI & 716 & $398(87.7 \%)$ & $31(7.2 \%)$ \\
\hline Beta-adrenergic receptor blockers & 429 & $331(89.0 \%)$ & $41(11.0 \%)$ \\
\hline CCBs & 372 & $111(98.2)$ & $3(2.6 \%)$ \\
\hline CAAAs & 114 & $61(93.8 \%)$ & \\
\hline & 65 & $\mathbf{2 4 6 0}$ & \\
\hline
\end{tabular}

$P \geq 0.05(C I=95 \% ; d f=6)$

Table 2: Rate of discontinuation of treatment due to adverse drug effect within each class of antihypertensive

\begin{tabular}{|c|c|c|c|}
\hline \multirow[t]{2}{*}{$\begin{array}{l}\text { Class of antihypertensive } \\
\text { drug }\end{array}$} & \multirow[t]{2}{*}{$\begin{array}{l}\text { Total exposure } \\
\text { (prescriptions) of drugs }\end{array}$} & \multicolumn{2}{|c|}{$\begin{array}{l}\text { Frequency (percentage) of discontinuation of treatment due to } \\
\text { adverse drug effect of antihypertensive }\end{array}$} \\
\hline & & No & Yes \\
\hline Diuretics & 749 & $10(1.3 \%)$ & $25(3.3 \%)$ \\
\hline ACEI & 716 & 1 & $87(12.2 \%)$ \\
\hline Adrenergic beta-receptor blockers & 429 & $7(1.6 \%)$ & $24(5.5 \%)$ \\
\hline CCBs & 372 & $8(2.2 \%)$ & $33(8.9 \%)$ \\
\hline CAAAs & 114 & $3(2.6 \%)$ & $0(\%)$ \\
\hline adrenergic $\alpha$-receptor blockers & 65 & 0 & $4(6.2 \%)$ \\
\hline Total & 2460 & & $173(7 \%)$ \\
\hline
\end{tabular}

Table 3: Distribution of specific adverse drug effect experienced from Angiotensin I converting enzyme inhibitor (ACEI) (n= 88)

\begin{tabular}{|c|c|c|c|c|}
\hline \multirow{2}{*}{ ACEI } & \multicolumn{3}{|c|}{ Frequency of specific adverse drug effect experienced (percentage) } \\
\cline { 2 - 5 } & Hypotension & Dry cough & \multicolumn{2}{c|}{ Headache } \\
\hline Captopril & $7(8 . \%)$ & $42(47.7 \%)$ & 0 & $0(0 \%)$ \\
\hline Linosopril & $3(3.4 \%)$ & $34(38.6 \%)$ & $0(0 \%)$ & $0(0 \%)$ \\
\hline Ramipril & $0(0 \%)$ & $2(2.3 \%)$ & $0(0 \%)$ & $\mathbf{0}(\mathbf{0} \%)$ \\
\hline Total (n= 88) 100\% & $\mathbf{1 0}(\mathbf{1 1 . 4 \% )}$ & $\mathbf{7 8 ( 8 8 . 8 \% )}$ & $\mathbf{0 ( 0 \% )}$ \\
\hline
\end{tabular}

Table 4: Distribution of specific adverse drug effect experienced from Calcium channel blockers $(n=41)$

\begin{tabular}{|c|c|c|c|c|}
\hline \multirow{2}{*}{$\begin{array}{c}\text { Calcium channel } \\
\text { blocker }\end{array}$} & \multicolumn{4}{|c|}{ Frequency of specific adverse drug effect experienced (percentage) } \\
\hline & Bradycardia & Headache & oedema & Abdominal pain \\
\hline Nifedipine & $2(5.9 \%)$ & $19(55.9 \%)$ & $13(38.2 \%)$ & $0(0 \%)$ \\
\hline Amlodipine & $1(14.3 \%)$ & $2(28.6 \%)$ & $2(28.6 \%)$ & $2(28.6 \%)$ \\
\hline Total $(n=41)$ & $3(7.3 \%)$ & $21(51.2 \%)$ & $15(36.6 \%)$ & $2(4.9 \%)$ \\
\hline
\end{tabular}

Table 5: Distribution of specific adverse drug effect experienced from Beta-adrenergic receptor blocker $(n=31)$

\begin{tabular}{|c|c|c|c|c|}
\hline \multirow{2}{*}{$\begin{array}{c}\text { Beta-adrenergic } \\
\text { receptor blocker }\end{array}$} & Fypotension & Bradycardia & \multicolumn{2}{|c|}{ Insomnia } \\
\cline { 2 - 5 } & $5(16.1 \%)$ & $15(48.4 \%)$ & $7(22.5 \%)$ & Fatigue and cold extremities \\
\hline Atenolol & $3(9.7 \%)$ & $0(0 \%)$ & $0(0 \%)$ & 0 \\
\hline Propranolol & $0(0 \%)$ & $0(0 \%)$ & $1(3.2 \%)$ & $0(0 \%)$ \\
\hline Cavidalol & $\mathbf{8 ( 2 5 . 8 \% )}$ & $\mathbf{1 5}(\mathbf{4 8 . 4 \% )}$ & $\mathbf{8}(\mathbf{2 5 . 8} \%)$ & $0(0 \%)$ \\
\hline Total (n= 31) $\mathbf{1 0 0} \%$ & $\mathrm{P} \geq 0.05(\mathrm{CI}=95 \% \mathrm{df}=4)$ & $\mathbf{0}(\mathbf{0} \%)$ \\
\hline
\end{tabular}

Table 6: Distribution of specific adverse drug effect experienced from Diuretics $(n=35)$

\begin{tabular}{|c|c|c|c|c|}
\hline \multirow[t]{2}{*}{ Diuretics } & \multicolumn{4}{|c|}{ Frequency (percentage)of specific adverse drug effect experienced } \\
\hline & Dehydration & Hypokalaemia & Hypouricaemia & Fatigue \\
\hline Bendroflumethiazide & $3(8.6 \%)$ & $4(11.4 \%)$ & $4(11.4 \%)$ & $2(5.7 \%)$ \\
\hline Frusemide & $3(8.6 \%)$ & $15(42.9 \%)$ & $1(2.8 \%)$ & $3(8.6 \%)$ \\
\hline Hydrochlorothiazide & 0 & 0 & 0 & 0 \\
\hline Spirinolactone & 0 & 0 & 0 & 0 \\
\hline Total $(n=35) 100 \%$ & $6(17.2 \%)$ & $29(54.3 \%)$ & $5(14.2 \%)$ & $5(14.2 \%)$ \\
\hline
\end{tabular}




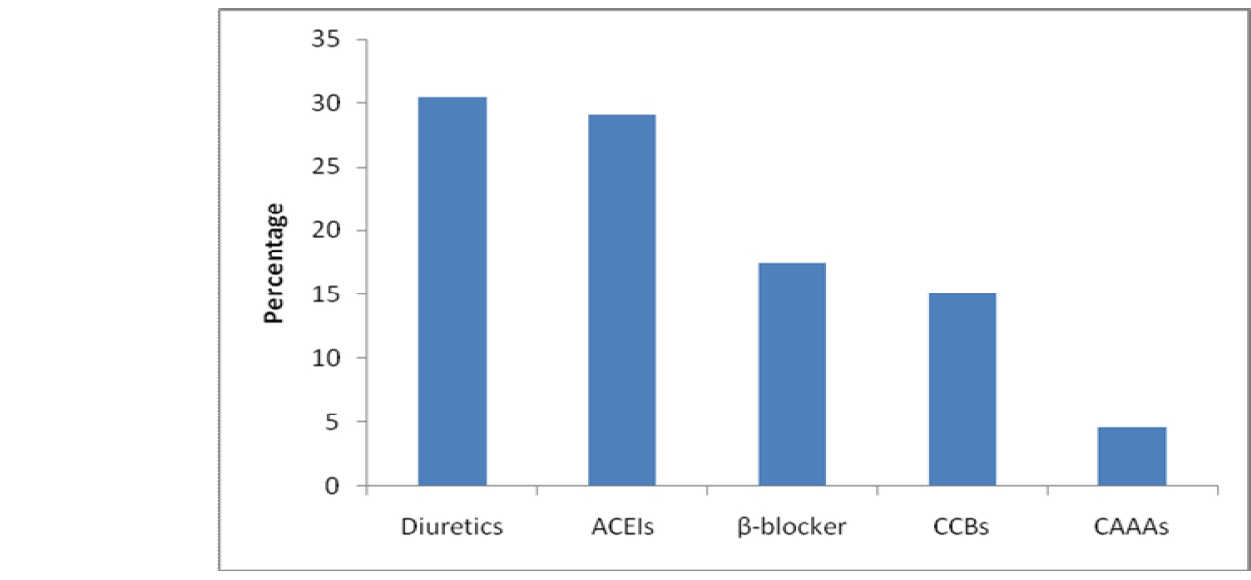

Figure 1: Percentage distribution of classes of anti hypertensive drugs ACEIs - Angiotensin converting enzyme inhibitors; $\beta$-blockers - Beta-adrenergic receptor blockers; CCBs - Calcium channel blockers; CAAAs - Centrally acting adrenergic antagonists

\section{RESULTS}

One thousand, one hundred and sixty-four (1164) patients (728 males and 536 females with the mean age of $47 \pm 14.2$ ) had 2460 exposures (prescriptions) of various classes of antihypertensive drugs. The most frequently prescribed were: diuretics 749 (30.4\%), ACE inhibitors 716 (29.1\%), followed by beta blockers 429 (17.4\%), calcium channel blockers (CCBs) 372 (15.1\%) and centrally acting adrenergic agonists (CAAAs) $114 \quad(4.6 \%)$ [Figure1]. The distribution of frequency and percentage of adverse effects experienced from each class of antihypertensive drugs are shown in Table 1. Also the rates of discontinuation of treatment due to adverse effects within class of antihypertensive drugs are shown in Table 2, while the distribution of proportions of specific adverse effects due to various drugs within each class of antihypertensive drugs are as shown in Tables 3 to 6 .

\section{DISCUSSION}

A total of $202(8.2 \%)$ adverse drug effects were observed in 1164 hypertensive patients ( 728 males and 536 females) from the total of 2460 antihypertensive drug exposures (prescriptions) and the mean age of $47.66 \pm 14.23$ during the period of 2003-2004 in UMTH. A higher percentage of adverse drug effects occurred in females 116 (57.4\%) than 86 $(42.57 \%)$ of males, the finding was in agreement with that reported by Raghu et $\mathrm{al}^{15}$ and Prasad et $\mathrm{al}^{16}$ respectively, which revealed that a higher percentage of adverse drug effect occurred in females $(58.80 \%)$ than males $(41.2 \%)$. Also the incidence of discontinued treatment occurred more in females $17(10.2 \%)$ than males $14(8.4 \%)$, though the observed difference between the sex groups was not statistically significant $(p>0.05)$. Theoretically women were thought to be at greater risk of adverse drug reaction than men, which might be due to gender related differences in pharmacokinetics, immunology and hormonal factors. However, a recent survey by Walker and Whittlesea ${ }^{5}$ revealed that the overall tolerability of low to moderate-dose antihypertensive medicines was similar in men and women.

Of the total of 202 adverse drug effects observed across the different classes of antihypertensive drugs (Table 1), the most commonly implicated were ACE inhibitors with an incidence of $12.3 \%$, followed by calcium channel blockers (CCBs) $11.2 \%$ and beta-adrenergic receptor blockers $7.2 \%$. The least implicated were diuretics (4.7\%), even though they were the most commonly prescribed. These findings were consistent with those reported by Singhal et $\mathrm{al}^{17}$ in which $\mathrm{CCBs}$ and ACE inhibitors were the most often implicated with highest incidence of adverse drug effect but contrast to findings of Prasad et $\mathrm{al}^{16}$ in which beta-blockers and ACE inhibitors were associated with higher incidences of ADRs.

The overall rate of discontinuation of treatment due to adverse effects across the different classes of antihypertensive drugs was (7\%), i.e. of the total of 202 observed adverse effects, $173 \quad(84.2 \%)$ resulted in discontinuation of treatment. ACE inhibitors were the most commonly discontinued therapeutic class $(12 \%)$ followed by CCBs (8.9\%), adrenergic $\alpha$-receptor blockers (6.2\%), beta adrenergic receptor blockers (5.5\%) and diuretics (3.3\%). This demonstrated that users of diuretics had the lowest rate of discontinuation of treatment with the greatest tolerability. This finding concurred with another study ${ }^{18}$ which reported the lowest rates of discontinuation due to diuretics In this study, the most common reason cited for discontinuation of ACE inhibitors was cough, thus, supporting the finding by Alderman ${ }^{19}$. Linosopril appearing to be better tolerated than captopril with discontinuation rates of $39 \%$ vs $48 \%$ respectively [absolute risk reduction (ARR) calculated to be $9 \%$, number need to harm $(\mathrm{NNH})=9$, i.e. for every eight patients treated with captopril instead of linosopril one patient will discontinue treatment due to cough]. Though the incidence of headache $(56 \%)$ was higher than peripheral oedema $(38 \%)$ in hypertensive patients treated with CCBs, peripheral oedema was the main reason cited in the patients' records for discontinuation of the treatment. This finding was supported by the reports of stus ${ }^{20}$, ${ }^{21}$ which revealed that peripheral oedema was the most common reason cited for discontinuation of CCBs. Within $\mathrm{CCBs}$, the rate of discontinuation was higher with nifedipine than amlodipine $(38 \%$ vs $28 \%$ ) respectively (ARR) $=10 \%$, implying the later was better tolerated than the former. This finding concurred with the report of a study by Hosu et $\mathrm{al}^{22}$ that a higher incidence of adverse drug reactions with attendant rate of discontinuation was associated with nifedipine compared to amlodipine.

Within beta-adrenergic receptor blockers, the most common reason cited for discontinuation of treatment was bradycardia, with propranolol appearing to be better tolerated than atenolol $48 \%$ vs $0 \%$ respectively. On the contrary, another study $^{23}$ revealed that impotence was a common complaint with this class of drugs. 
Within the diuretics class, frusemide recorded the highest incidence of adverse drug reactions mainly hypokalaemia (43\%), followed by Bendroflumethiazide (11\%), and with the lowest incidence reported in Hydrochlorothiazide (3\%). There was statistical significant difference in the distribution of hypokalaemia. Though the major adverse drug reaction of diuretics recorded in this study was hypokalaemia, a previous study ${ }^{24}$ reported the incidence of impotence as high as $31 \%$. Overall, the discontinuation rates for the antihypertensensive drugs within therapeutic class varied, and this might be related to the relative frequency of adverse effects of each drug. This finding is in agreement with that reported by Baqir. ${ }^{14}$ The important factors in the management of hypertension are achieving a targeted level of blood pressure control and ensuring the patient remains using the drug over a long term. This study shows that selecting drugs with the lowest incidence of adverse effects from within the same therapeutic class may lead to persistence with treatment and achieving blood pressure control. Thus, the risk of developing cardiovascular complications can be reduced.

\section{CONCLUSION}

Therefore, the evaluation of the relative incidence of adverse effects and treatment discontinuation among the antihypertensive drugs offer the best opportunity to detect differences among the individual drugs within the same therapeutic class.

\section{ACKNOWLEDGEMENT}

We wish to express our profound appreciation to Dr Abdullahi Mohammed Telle, Consultant Cardiologist and his team for all the support rendered in carrying out this study.

\section{REFERENCES}

1. Dhikav V, Singh S, Anand KS. Adverse drug reaction monitoring in India. J Indian Acad Clin Med, 2004; 5:27-3.

2. Stamler J, Stamler R, Neaton JD. Blood pressure, systolic and diastolic, and cardiovascular risks vs. population data. Archives of Internal Medicine, 1993; 153: 598-615. http://dx.doi.org/10.1001/archinte. 1993.00410050036006 PMid:8439223

3. Fernando S Antezana. Epidemiological aspects of hypertension in the world. N Engl J Med, 1996; 352:1824-5.

4. Obinna IE and Cletus NA. A meta-analysis of prevalence rate of hypertension in Nigerian population. Journal of public health and education 2011; 3(13): 604-607.

5. Walker R and Whitlesea C. Clinical Pharmacy and Therapeutics, 4th edition 2007: page 51-59, 265, 269-270.

6. British Hypertension Society guideline for hypertension management BHS. (BHS-IV): Summary by Williams B, Poulter NR, Brown MJ, Mark Davis, Gordon T. Melnnes John F. Potter, Sean P, Simon McG Thon, The BHS guidelines working party, for the British hypertension society 2004; page:637-640.
7. NICE Guideline -. CG34 Hypertension. London: National Institute for Health and Clinical Excellence 2006; [website] http://www.nice.org.uk (accessed May 9, 2013).

8. Rizos EV et al. Manidipine: A different dihydropyridine. World Journal of Hypertension, 2011; 1(1): 3-6. http://dx.doi.org/10.5494/wjh.v1.i1.3

9. Wallander M.A, Dimenas E, Svardsudd K, Wiklund I. Evaluation of three methods of symptom reporting in a clinical trial of felodipine. Eur J Clin pharmacol 1991; 41:187-96. http://dx.doi.org/10.1007/ BF00315428 PMid:1748134

10. Olsen H, Klemetsrud T, Stokke HP, Tretlis T, Westheim A. Adverse drug reactions in current antihypertensive therapy: A general practice survey of 2586 patients in Norway. Blood Press 1999; 8: 94-101. http://dx.doi.org/10.1080/080370599438266 PMid:10451036

11. Parthasarathi G, Olsson S. Adverse drug reactions. In: Parthasarathi G, Nyfort-Hansen K, Nahata MC, editors. A textbook of clinical pharmacy practice, (Eds). Chennai: Orient Longman Pvt Ltd, 2004; 84-102.

12. Hussain A, Aqil M, Alam MS, Khan MR, Kapur P, Pillai KK. A pharmacovigilance study of antihypertensive medicines at a South Delhi hospital. Indian J Pharm Sci 2009;71:338-41. http://dx.doi.org/10.4103/ 0250-474X.56018 PMid:20490310 PMCid:2865802

13. Anon.2 Adverse effects 2009 [website] http://informahealthcare.com// Adverse effect (accessed May 9, 2013).

14. Baqir W. A retrospective evaluation of the relative incidence of adverse effects of recommended antihypertensive drugs: are there differences within the same therapeutic class? Intern J Pharm Practice (IJPP) 2008; SS (3)16: C65.

15. Raghu VS, Ram RV, Prasad GB, Mohanta PG, Manna KP. A study of adverse drug reactions due to antihypertensive drugs in a tertiary care teaching hospital. International Journal of Pharmacy \& Life Sciences, 2011; 2(5): 767-768.

16. Prasad GB, Mohanta PG, Manna KP et al. A study of adverse drug reactions due to antihypertensive drugs. International Journal of Pharmacy and Life Sciences 2001; 2(5): 767-768.

17. Singhal R, Ahmed K, Santani D. Reporting and monitoring of adverse drug reactions with cardiac drug. International Research Journal of Pharmacy. 2001; 2 (7): 116-119.

18. Omgas G. Adverse effects with antihypertensives. Health mad April 2nd, 2011.

19. Alderman CP. Adverse effects of the angiotensin-converting enzyme inhibitors. Ann Pharmacother, 1996; 30:55-61. PMid:8773167

20. VanZwieten PA. Clinical pharmacology of calcium antagonists as antihypertensive and antianginal drugs. J Hypertens, 1996; 14(3):3-9. http://dx.doi.org/10.1097/00004872-199610003-00002

21. Borrild NJ. Patients' experiences of antihypertensive drugs in routine use: results of a Danish general practice survey. Blood Press1997; 6:2325.

22. Hosu CY, McCulloch CE, Darbinian J, Go AS, Iribarren C. Elevated blood pressure $2005 \mathrm{http} / /$ en.wikipedia.org/wiki/Antihypertensive (accessed on 12/6/2013.

23. Jacob S, Rett K, Henriksen EJ. Antihypertensive therapy and insulin sensitivity: do we have to redefine the role of ß-blocking agents? Am J Hypertens 1998; 11:1258-65. http://dx.doi.org/10.1016/S08957061(98)00141-1

24. Rosen RC. Sexual dysfunction as an obstacle to compliance with antihypertensive therapy. Blood Pressure, 1997; 6(1):47-51.

\section{Cite this article as:}

Yakubu Sani Ibn, Fave Tata, Giwa Abdulganiyu, Muazu Jamilu and Mohammed Garba Tom. Evaluation of the relative incidence of adverse effects leading to treatment discontinuation of recommended antihypertensive drugs. Int. Res. J. Pharm. 2013; 4(6):58-61 